\title{
PENGARUH PROMOSI DAN KUALITAS TERHADAP INTENTION TO USE JASA TRANSPORTASI PT. BATAM FAST FERRY DI KOTA BATAM
}

\author{
Agung Edy Wibowo ${ }^{1}$, Frangky Silitonga ${ }^{2}$ \\ Sekolah Tinggi Ilmu Kesehatan Awal Bros Batam, Provinsi Kepulauan Riau, Indonesia \\ edywbw.11@gmail.com ${ }^{1}$ \\ Universitas Karimun, Provinsi Kepulauan Riau, Indonesia \\ frangkyka@gmail.com ${ }^{2}$
}

\begin{abstract}
Abstrak
Dalam penelitian ini desain penelitian yang digunakan adalah eksplanatori dengan tujuan untuk menganalisis hubungan antar variabel melalui uji hipotesis yang telah dibangun. Sampel yang digunakan dalam penelitian ini adalah sebanyak 100 responden. Teknik analisis data yang digunakan dalam studi ini adalah analisis regresi linier berganda yang bertujuan untuk menguji hubungan dan pengaruh antara variabel bebas dan variabel terikat. Hasil dari penelitian ini adalah : 1) Variabel promosi secara parsial memiliki pengaruh terhadap intention to use jasa transportasi PT Batam Fast Ferry. 2) Variabel kualitas pelayanan secara parsial memiliki pengaruh terhadap intention to use jasa transportasi PT Batam Fast Ferry. 3) Variabel kualitas pelayanan memiliki pengaruh lebih dominan terhadap intention to use jasa transportasi PT Batam Fast Ferry.
\end{abstract}

Kata Kunci : Promosi, Kualitas, Intention to use

\section{PENDAHULUAN}

Indonesia sebagai negeri kepulauan yang memiliki wilayah perairan 2.3 dari luas wilayah yang ada sudah selayaknya memiliki armada transportasi ynng memadai guna melayani masyarakat dengan baik, disamping armada angkutan udara. Dalam era globalisasi saat ini kompetisi dalam bidang transportasi laut telah menjadi ceruk baru dalam model layanan transportasi umum dan telah meningkat dalam dekade persaingan antar perusahaan bahkan lintas Negara. Ketersediaan sarana transportasi laut telah menjadi penghubung dan memicu aeus lalu lintas orang dengan semua kepentingan bisnisnya. Fungsi dari sarana perhubungan ini dapat membantu pemerataan hasil pembangunan, memperkokoh persatuan dan kesatuan bangsa, dan tentu saja dapat menjadi sarana untuk meningkatkan laju ekonomi suatu bangsa.

Industri jasa angkutan laut dengan menggunakan kapal laut merupakan jasa angkutan yang berperan dalam jasa pengangkutan barang dan penumpang. Sektor transportasi selain Didalam sistem transportasi nasional terdapat sektor kepelabuhan bagian strategis dari perdagangan. Sektor pelabuhan memerlukan suatu kesatuan yang terintegrasi dalam melayani kebutuhan dari sarana transportasi. Transportasi laut dapat menunjang perekonomian dalam Negara dengan memudahkan transfer teknologi, ilmu pengetahuan maupun perdagangan. Transportasi laut yang berupa kapal menyediakan berbagai macam tawaran yang disesuaikan kebutuhan masyarakat.

Batam sebagai sebuah provinsi muda telah menunjukan geliat kehidupan ekonomi yang cukup baik, letaknya yang strategis dan kultur budaya yang plural telah menjadi tempat yang menarik bagi kehidupan perekonomian dan bisnis. Letak yang strategis Batam telah menjadi 
target bagi hampir semua industri di kota ini, dari indusrti kecil maupun industri besar sekelas fabrikasi, manufaktur dan jasa. Salah satu dari industri manufaktur yang ada adalah industri perkapalan. Dan bagian dari separuh indusrti perkapalan yang ada adalah pembuatan kapal angkut orang dan barang. Jasa transportasi laut memiliki keunikan tersendiri, karena transportasi laut dapat memindahkan orang maupun barang dari tempat yang satu ke tempat yang lainya dalam jumlah yang besar. Untuk memenangkan persaingan, perusahaan harus mampu memberikan kepuasan kepada para pelanggannya. Dalam situasi persaingan bisnis yang semakin ketat ini, perusahaan-perusahaan jasa atau penyedia-penyedia jasa harus dapat melihat faktor-faktor apa saja yang penting dan memengaruhi tingkat penjualan, kepuasan pelanggan, serta loyalitas para pelanggannya demi kelangsungan bisnis perusahaan itu sendiri.

Sebagai kota industri Baru, Kota Batam hampir disinggahi para pekerja dari beberapa para pekerja dari lintas pulau, bahkan lintas Negara. Ada lebih dari 5 perusahaan besar jasa transportasi barang dan orang yang menjalankan atau menjadi operator yang melayani konsumen tersebut. Perusahaan perlu melakukan kajian terhadap profiling konsumen sehingg dapat dengan baik memberikan layanan yang maksimal bagi kosnumen pada saat mereka menggunakan jasa layanan transportasi tersebut. Hal ini perlu dilakukan karena hasil kajian akan memberikan informasi yang lebih baik tentang konsumen dan selanjutnya perusahaan dapat memilih menerapkan strategi pemasaran yang baik dalam mempengaruhi pelanggan atau konsumennya.

Bagian dari cara mempengaruhi konsumen dapat dilakukan melalui promosi salah satunya adalah advertising atau periklanan (Kotler, 2012). Periklanan yang merupakan bagian dari promosi dan menjadi bauran pemasaran sangatlah powerful dalam mempengaruhi benak konsumen, dengan periklanan konsumen akan diingatkan kebaradaan sebuah produk atau jasa, dengan periklanan konsumen atau pelanggan dapat diberi informasi kebaruan dari sebuh produk atau jasa, dengan periklanan konsumen dapat dipengaruhi untuk bertindak sesuai dengan keinginan pengiklan. Jika iklan yang disampaikan sampai pesanya kepada kosnumen hal ini dapat menimbulkan tindakam dari penerima iklan tersebut.

Atribut lain yang dipertimbangkan oleh konsumen pada saat ing melakukan pilihan untuk membeli atau menggunakan adalah pertimbangan kualitas dari sebuah produk atau jasa yang ditawarkan. Kualitas yang dipersepsikan sebagai keadaan yang memenuhi nilai atau melebihi sebuah nilai yang dipersepsikan konsumen dapat menjadi suplemen penting yang dipertimbangkan konsumen untuk memilih sebuah produk atau jasa yang sedang mereka cari. Kualitas dapat dipersepsikan sebagai mutu atau performa produk atau layanan yang dapat memberi kepuasaan kepada konsumen setelah konsumen tersebut membeli dan mencobanya, jika konsumen merasa senang dan puas ataus kinerja atau nilai sebuah produk atau jasa maka produk atau jasa tersebut dianggap memiliki kualitas oleh konsumen tersebut. atirbut mana dalam promosi yang akan dilakukan. Pilihan tersebut sangat bergantung dari kajian awal tentang konsumen yang telah dipelajari tersebut.

Menurut (Tjiptono, 2014) pada prinsipnya kualitas jasa (dalam hal ini adalah kualitas pelayanan) berfokus pada upaya pemenuhan kebutuhan dan keinginan pelanggan serta ketepatan penyampaiannya untuk mengimbangi harapan pelanggan. Dengan memberikan kualitas pelayanan yang baik akan memberikan suatu dorongan kepada pelanggan untuk menjalin ikatan kebutuhan yang kuat dengan perusahaan. Apabila kualitas pelayanan semakin baik, ditunjukkan dengan pelayanan yang handal, memiliki daya tanggap, memiliki jaminan pelayanan dan empati (rasa perhatian) yang lebih, maka konsumen akan merasa puas. Bagian manakah yang perlu ditonjolkan dan bagian mana yang tidak, hal itu akan melekat pada produk atau jasa atau layanan yang diberikan pada konsumen atau pelanggan dari perusahaan. Para pemasar perlu dengan baik mengkaji dari setiap produk atau layanan yang diberikan oleh 
perusahaan pada konsumenya. Kedua tahapan di atas dilakukan dalam rangka menciptakan kondisi memicu niat mencoba (intention to use) sebuah produk atau layanan.

Intention to use atau niat menggunakan dapat menjadi tolak ukur utama keberhasilan sebuah promosi dan sekaligus layanan yang dilakukan oleh perusahaan. Promosi yang efektif dalam jasa transportasi laut adalah dengan pembuktian pelayanan yang baik, karena dengan pemberian pelayanan inilah maka kedepan konsumen akan melakukan pembelian atau penggunaan ulang dari jasa yang telah digunakanya. Dengan pembuktian ini maka spreading the good nres melalui words of mouth dapat terjadi, dan berakibat poitif bagi perusahaan. Selian tentu saja melakukan proses promosi konvensional melalui below the line dan above the line. Selanjutnya dengan produktif dan efektif memberikan pelayanan jasa yang memenuhi kriteria service quality yang meliputi empathy, assurance, tangible, responsiveness, reliability (Kotler, 2012).

PT Batam Fast Ferry adalah perusahaan yang bergerak di bidang transportasi penumpang yang melayani rute Batam - Singapur, Singapyra - Batam, Batam-Johor, dan Johor - Batam. PT Batam Fas Ferry dalam perjalannya terus mengupayakan dua jenis kegiatan tersebut yaitu; promosi dan melakukan upaya perbaikan kualitas pelayanan dengan satu tujuan untuk memperoleh peningkatan pengguna atau penumpang untuk menggunakan perjalanan lautnya menggunakan alat atau jasa transportasi PT Batam Fast Ferry. Berdasarkan latar belakang tersebut ;

1. Apakah promosi berpengaruh terhadap intention to use jasa transportasi pada PT. Batam Fast Ferry di Kota Batam?

2. Apakah kualitas pelayanan berpengaruh terhadap intention to use jasa transportasi pada PT. Batam Fast Ferry di Kota Batam?

3. Apakah kualitas pelayanan lebih dominan berpengaruh terhadap intention to use jasa transportasi pada PT. Batam Fast Ferry di Kota Batam?

\section{LANDASAN TEORI}

\section{Promosi}

Promosi dapat diberikan pengertian sebagai berikut promotion means activities that communicate the merits of the product and persuade target customers to buy it (Kotler and Keller, 2012). Pengertian diatas dapat dimaknai sebagai sebagai berikut, promosi merupakan kegiatan yang mengomunikasikan manfaat dari sebuah produk dan membujuk target konsumen untuk membeli atau menggunakan produk atau jasa tersebut. Tujuan promosi adalah meningkatkan penjualan, sedangkan tujuan spesifiknya menurut (Griffin and Elbert, 2012)adalah untuk:

\section{Communicate Information}

Pelanggan tidak akan membeli produk kecuali mereka mengenal produk tersebut. Informasi dapat memberi saran kepada pelanggan bahwa produk tersebut ada, atau informasi juga dapat memberikan pemahaman tentang corak produk

\section{Product Positioning}

Posisioning merupakan proses menetapkan identitas citra produk yangmudah dipahami dalam benak pelanggan. Posisioning produkakan sulit dilakukan jika organisasi bisnis mencoba memasuki pasar pelanggan secara keseluruhan, sehingga pendekatan segmen pasar yang spesifik dipandang lebih tepat untuk dilakukan. 


\section{Added Value}

Bauran promosi dirancang untuk mengkomunikasikan produk agar memiliki keuntungan nilai tambah.Promosi juga merupakan pemimpin dalam menetapkan nilai produk yang dirasakan bagi pelanggan.

\section{Control Sales Volume}

Promosi dengan periode yang lambat akan mengkontrol organisasi bisnis agar mampu menjaga system produksi dan distribusi supaya mampu berjalan dengan baik, dimana volume penjualan akan stabil sepanjang tahun.

\section{Kualitas Pelayanan}

Menurut (Kotler, 2012) kualitas pelayanan adalah penilaian konsumen tentang kehandalan dan superioritas pelayanan secara keseluruhan dimana konsumen akan membuat perbandingan dalam bentuk rasa puas antara yang mereka rasakan dengan apa yang mereka dapatkan. Menurut (Dharmmesta, 2009.) kualitas Pelayanan adalah segala bentuk aktivitas yang dilakukan oleh perusahaan guna memenuhi harapan konsumen.

Kualitas pelayanan dapat didefinisikan sebagai, the extent of discrepancy between customers expactations or desire and their. Dari pernyataan ini dikemukakan bahwa kualitas pelayanan yang diterima konsumen dinyatakan besarnya perbedaan antara harapan atau keinginan konsumen dengan tingkat persepsi mereka. Kualitas pelayanan sebagai irisan dari persepsi tentang kepuasan hal ini berarti penilaian seberepa jauh perbedaan antara kenyataan dan harapan pelanggan atas layanan yang mereka terima atau diperoleh. Kualitas tersebut merupakan totalitas fitur atau karakterisitik produk atau jasa dalam menunjukan performanya dan memuaskan pelangganya (Wibowo, 2017).

Karakteristik jasa/pelayanan sebagai berikut (Tjiptono, 2008):

1. Intangibility (tidak terwujud).

Jasa pelayanan tidak dapat dilihat, dirasa, diraba, didengar, atau dicium sebelum jasa/pelayanan itu dibeli. Nilai penting dari hal ini adalah nilai tidak terwujud yang dialami konsumen dalam bentuk kenikmatan, kepuasan, atau rasa aman.

2. Unstorability (tidak data disimpan).

Jasa/pelayanan tidak mengenal persediaan atau penyimpanan dari produk yang telah dihasilkan. Karakteristik ini disebut juga inseparability (tidak dapat dipisahkan) mengingat pada umumnya jasa/pelayanan dihasilkan dan dikonsumsi secara bersamaan.

3. Customization (kustomisasi).

Jasa/pelayanan sering kali didesain khusus untuk kebutuhan pelanggan

\section{Intention to use}

Menurut (Kotler dan Kelller, 2012) intention to use merupakan derivatif dari tujuan spesifik sebuah intention atau niat. Intention to buy atau minat beli adalah kondisi psikologis pelanggan yang dimotivasi perepsi, kognisi dan konasi yang menjadikan pelanggan memiliki (willingness) untuk bertindak membeli (to purchase) menggunakan ( to use), dan membelanjakan (to buy) terhadap produk atau jasa pihak lain yang ditawakan.

Satu dari beberapa faktor utama yang mempengaruhi perilaku pembelian konsumen, yaitu faktor psikologis. Faktor tersebut terdiri dari (Rangkuti, 2009);

1. Motivasi

Seseorang mempunyai banyak kebutuhan pada waktu tertentu dan dan kebutuhan akan menjadi motif yang mempengaruhi jika di dorong sampai mencapai tingkat intensitas yang memadai.

2. Persepsi 
Seseorang yang termotivasi siap untuk bertindak dan dipengaruhi oleh persepsinya terhadap situasi tertentu. Persepsi merupakan proses bagaimana seseorang memilih, mengorganisasikan, dan menginterprestasikan informasi untuk menciptakan gambaran dunia yang memiliki arti. Orang dapat memiliki persepsi yang berbeda atas objek yang sama.

3. Pembelajaran

Pembelajaran meliputi perubahan dalam perilaku seseorang yang timbul dari pengalaman.

4. Keyakinan dan Sikap

Melalui bertindak dan belajar, orang akan mendapatkan keyakinan dan sikap. Hal ini kemudian mempengaruhi tindakan mereka.

\section{Model Analisis}

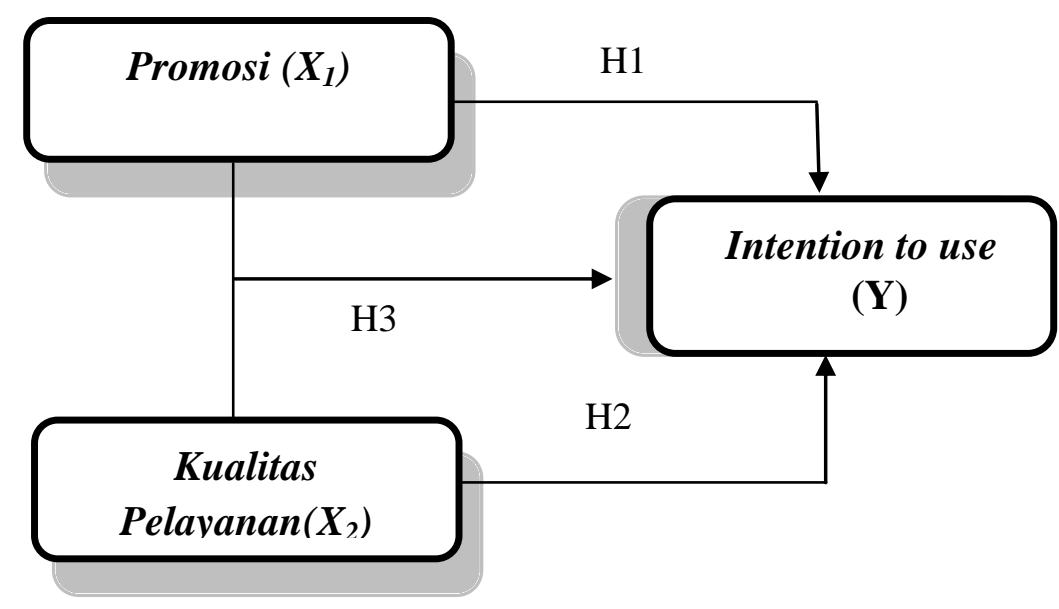

\section{Gambar 1.}

Model Analisis

\section{Hipotesis}

H1 : Promosi berpengaruh signifikan terhadap intention to use jasa transportasi pada PT. Batam Fast Ferry di Kota Batam.

$\mathrm{H} 2$ : Kualitas pelayanan berpengaruh signifikan signifikan terhadap intention to use jasa transportasi pada PT. Batam Fast Ferry di Kota Batam.

H3 : Kualitas pelayanan lebih dominan berpengaruh terhadap intention to use jasa transportasi pada PT. Batam Fast Ferry di Kota Batam.

\section{METODOLOGI PENELITIAN}

\section{Jenis Penelitian}

Dalam penelitian ini desain penelitian yang digunakan adalah eksplanatori dengan tujuan untuk menganalisis hubungan antar variabel melalui uji hipotesis yang telah dibangun. Teknik survey digunakan dalam penelitian ini untuk mendapatkan dan menggali sumber data dengan cara memberikan daftar pertanyaan kepada para responden dan kemudian mengumpulkanya, mengolahnya dan mengambil kesimpulan berdasarkan data yang telah diolah tersebut, sehingga metode statistika inferensial diterapkan dalam penelitian ini (Wibowo, 2013) 


\section{Populasi dan Sampel}

Populasi dalam penelitian ini adalah para pengguna alat transportasi PT Batam Fast Ferry di Kota Batam. Dengan memggunakan rumus populasi tidak diketahui

Keterangan

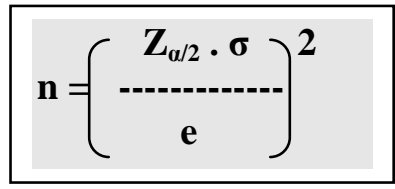

$\mathrm{n} \quad=$ Jumlah sampel

$\mathrm{Z}_{\alpha / 2}=$ ukuran tingkat kepercayaan dengan $\alpha=5 \%$, maka $\mathrm{Z}_{\alpha / 2}=1.96_{/ 2}$

$\sigma \quad=$ standard deviasi $=0.05$

e $\quad=$ kesalahan dalam pengambilam sampel $(5 \%)$

$$
n=\left(\begin{array}{c}
1,96_{/ 2} \cdot 0,05 \\
\hdashline 0,05
\end{array}\right)^{2}
$$

Hasil dari perhitungan di atas maka didapatkan jumlah sampel minimal sebesar 96.04 atau 100 (dibulatkan) responden. Guna memperoleh gambaran yang lebih baik telah disebarkan sejumlah kuesioner namun setelah proses penyaringan terdapat terdapat 112 jawaban responden yang layak untuk diolah. Pengambilan sampel dilakukan dengan teknik purposive sampling yaitu penentuan sampel dengan pertimbangan tertentu (Sugiyono, 2013). Adapun kriteria yang digunakan dalam pengambilan sampel adalah :

1. Warga Negara Indonesia tinggal di Batam

2. Telah lebih menggunakan Ferry Batam Fast lebih dari 3 kali.

3. Periode bepergian September 2019 sd Januari 2020

\section{Metode Pengumpulan Data}

Pengumpulan data dalam penelitian ini dilakukan dengan menyebarkan kuesioner dengan menghimpun daftar pertanyaan dari variabel promosi, kualitas pelayanan, dan variabel intention to use yang dirancang dalam suatu skala ukur dengan menggunakan alat ukur skala Likert 5 poin yang telah disesuaikan dengan rincian $1=$ sangat tidak setuju, $2=$ tidak setuju, 3 = cukup setuju, $4=$ setuju, dan 5 = sangat setuju.

Tabel. 1

\section{Definisi Operasional}

\begin{tabular}{|c|c|c|c|}
\hline Variabel & Pengertian & Indikator & Skala \\
\hline Promosi & $\begin{array}{l}\text { promotion means activities that } \\
\text { communicate the merits of the } \\
\text { product and persuade target } \\
\text { customers to buy it, (Kotler dan } \\
\text { Armstrong2012: } 76) \text {. }\end{array}$ & $\begin{array}{l}\text { 1,Jangkauan (Scope) } \\
\text { 2.Media saluran } \\
\text { (Channel) } \\
\text { 3.Kemudahan diingat } \\
\text { (To remind) } \\
\text { 4. Dampak pengaruh ( } \\
\text { To persuade) } \\
\text { 5.Biaya (Cost) }\end{array}$ & Likert \\
\hline
\end{tabular}




\begin{tabular}{|c|c|c|c|}
\hline $\begin{array}{l}\text { Kualitas } \\
\text { Pelayanan }\end{array}$ & $\begin{array}{l}\text { Kualitas pelayanan adalah } \\
\text { penilaian konsumen tentang } \\
\text { kehandalan dan superioritas } \\
\text { pelayanan secara keseluruhan } \\
\text { dimana konsumen akan } \\
\text { membuat perbandingan dalam } \\
\text { bentuk rasa puas antara yang } \\
\text { mereka rasakan dengan apa } \\
\text { yang mereka dapatkan. } \\
(\text { Barnes, 2015:45) }\end{array}$ & $\begin{array}{l}\text { 1. Wujud (Tangible) } \\
\text { 2. Kehandalan } \\
\text { (Reliability) } \\
3 \quad \text { Ketanggapan } \\
\text { (Responsiveness) } \\
\text { 4.Jaminan (Assurance) } \\
\text { 5.Empati (Emphaty) }\end{array}$ & Likert \\
\hline $\begin{array}{l}\text { Intention } \\
\text { Use } \\
\text { Menggunakan) }\end{array}$ & $\begin{array}{l}\text { kondisi psikologis pelanggan } \\
\text { yang dimotivasi perepsi, } \\
\text { kognisi dan konasi yang } \\
\text { menjadikan } 4 \text { pelanggan } \\
\text { memiliki (willingness) untuk } \\
\text { bertindak membeli (to } \\
\text { purchase) menggunakan ( to } \\
\text { use), dan membelanjakan (to } \\
\text { buy) terhadap produk atau jasa } \\
\text { pihak lain yang ditawakan. }\end{array}$ & $\begin{array}{l}\text { 1. Mencoba ( To try) } \\
\text { 2. Kembali } \\
\text { menggunakan (re- } \\
\text { use) } \\
\text { 3. Usaha nendapatkan( } \\
\text { effort most) } \\
\text { 4. Rencana memakai } \\
\text { (Planning to use) } \\
\text { 5. Tidak berpaling ( No } \\
\text { switching) }\end{array}$ & Likert \\
\hline
\end{tabular}

Sumber : Ringkasan Peneliti (2020)

\section{Teknik Analisis Data}

Teknik analisis data yang digunakan dalam studi ini adalah anaslisis regresi linier berganda yang bertujuan untuk menguji hubungan dan pengaruh antara variabel bebas dan variabel terikat (Ghozali, 2011). Analisis regresi linier berganda dalam penelitian ini diformulasikan sebaga berikut :

$\mathrm{Y}=\mathrm{a}+\mathrm{b}_{1} \mathrm{X}_{1}+\mathrm{b}_{2} \mathrm{X}_{2}+\mathrm{b}_{3} \mathrm{X}_{3}$

Keterangan :

$\mathrm{Y} \quad=$ Intention to use

a $\quad=$ Konstanata

$\mathrm{b} \quad=$ Koefisien regresi

$\mathrm{X}_{1,2,3}=$ Variabel independen

\section{Hasil dan Pembahasan}

Hasil kajian terhadap variabel yang digunakan dalam penelitian ini yang terdiri dari variabel promosi, kualitas pelayanan yang merupakan variabel independen dan variabel intention to use yang merupakan variabel dependen dapat disajikan seperti dalam tabel uji koefisein di bawah ini :

Tabel 2.

Hasil Analisis Statistik 


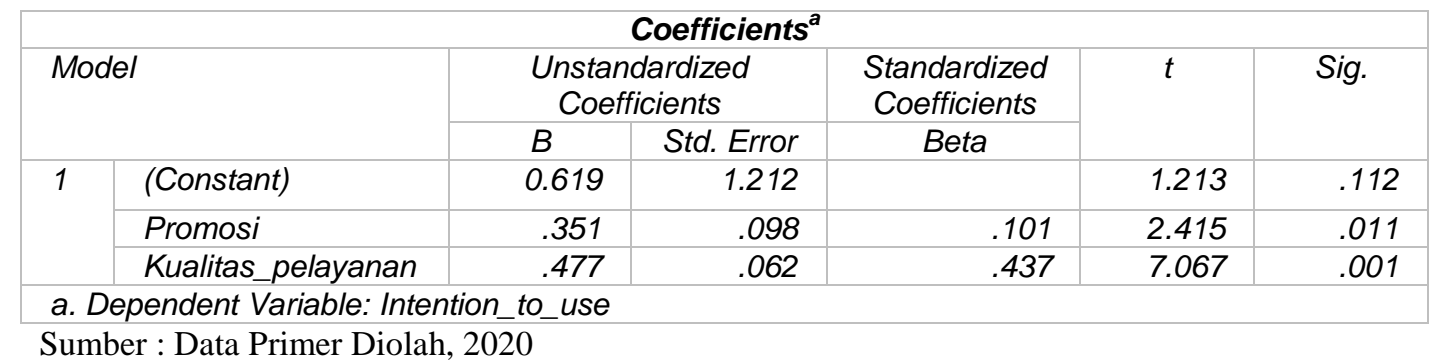

Sumber : Data Primer Diolah, 2020

Dari hasil regresi di atas maka diperoleh persamaan regresi sebagai berikut :

$\mathrm{Y}=0.619+0.351 \mathrm{X}_{1}+0.477 \mathrm{X}_{2}$

Artinya :

1) Nilai konstanta sebesar 0.619 memiliki arti bahwa jika variabel promosi dan kualitas pelayanan memiliki nilai 0 atau tidak berubah, maka variabel intention to use akan memiliki nilai sebesar 0.619 .

2) Nilai koefisien regresi untuk variabel promosi adalah sebesar 0.351, hal ini menunjukkan bahwa jika variabel promosi bertambah satu poin atau satu satuan maka variabel intention to use akan bertambah sebesar 0.351 dengan asumsi variabel lain tetap, tidak berubah.

3) Nilai koefisien regresi untuk variabel kualitas pelayanan adalah sebesar 0.477 dan hal ini menunjukkan bahwa jika variabel kualitas pelayanan bertambah satu poin atau satu satuan maka variabel intention to use akan bertambah sebesar 0.477 dengan asumsi variabel lain tetap, tidak berubah.

Sedangkan, koefisien determinasi $\left(\mathrm{R}^{2}\right)$ yang digunakan untuk menjelaskan proporsi variasi dalam variabel terikat (Y) yang dijelaskan oleh variabel bebas dapat dilihat pada tabel hasil uji koefisien determinasi berikut ini;

Tabel 3.

\section{Koefisien Detereminasi}

\begin{tabular}{|c|c|c|c|c|}
\hline \multicolumn{5}{|c|}{ Model Summary } \\
\hline Model & $R$ & $\begin{array}{c}R \\
\text { Square }\end{array}$ & $\begin{array}{l}\text { Adjusted } R \\
\text { Square }\end{array}$ & $\begin{array}{l}\text { Std. Error of } \\
\text { the Estimate }\end{array}$ \\
\hline 1 & $.620^{a}$ & .644 & .631 & 1.85676 \\
\hline
\end{tabular}

Berdasarkan tabel di atas dapat dilihat bahwa nilai $R$ Square sebesar 0.644 atau sebesar $64.4 \%$. Hal ini berarti variabel intention to use dapat dijelaskan oleh variasi variabel promosi dan kualitas pelayanan sebesar $64.4 \%$, sedangkan sisanya sebesar $35.6 \%$ dipengaruhi oleh faktor lain yang tidak disertakan dalam model penelitian ini.

\section{Uji t dan Faktor Dominan}

Uji t bertujuan untuk membuktikan hipotesis mengenai rata-rata suatu populasi. Uji ini juga digunakan untuk melihat atau meguji pengaruh secara individual suatu variabel independen terhadap variabel dependennya. Pada pengujian ini akan dilakukan dengan cara membandingkan tingkat signifikansi hasil uji dengan nilai $\alpha=0.05$ dan nilai thasil uji dengan nilai $t$ tabel pada taraf $\alpha=0.05$.

Hasil uji pada tabel 1. di atas menunjukan bahwa nilai signifikansi variabel promosi sebesar $0.011<0.05$ dan t hitung $2.415>\mathrm{t}$ tabel 1.9839 maka dapat dinyatakan bahwa 
variabel promosi memiliki pengaruh signifikan terhadap intention to use jasa transportasi PT Batam Fast Ferry.

Hasil uji pada tabel 1. di atas menunjukan bahwa nilai signifikansi variabel kualitas pelayanan sebesar $0.001<0.05$ dan t hitung $7.067>\mathrm{t}$ tabel 1.9839 maka dapat dinyatakan bahwa variabel kualitas pelayanan memiliki pengaruh signifikan terhadap intention to use jasa transportasi PT Batam Fast Ferry.

Dari hasil uji seperti pada tabel 1, dijelaskan bahwa besaran koefisien variabel kualitas pelayanan memiliki nilai $=0.477$ sedangkan nilai variabel promosi $=0.351$ serta nilai koefisien signifikansi variabel kualitas pelayanan $=0.001$ sedangkan nilai signifikansi variabel promosi $=0.011$, dengan demikian dapat disimpulkan bahwa variabel kualitas pelayanan lebih dominan berpengaruh terhadap intention to use dari responden atau pengguna jasa transportasi lau PT Batam Fast Ferry.

\section{KESIMPULAN}

\section{Kesimpulan}

Variabel promosi secara parsial memiliki pengaruh terhadap intention to use jasa transportasi PT Batam Fast Ferry. Variabel kualitas pelayanan secara parsial memiliki pengaruh terhadap intention to use jasa transportasi PT Batam Fast Ferry. Variabel kualitas pelayanan memiliki pengaruh lebih dominan terhadap intention to use jasa transportasi PT Batam Fast Ferry.

\section{Saran}

Diharapkan PT Batam Fast Ferry terus mempertahankan pola promosi yang telah dilakukan karena apa yang sekarang sedang dikerjakan telah terbukti mendorong konsumen untuk terus mau dan menggunakan alat transportasi tersebut dalam kegiatan mereka sehari. Kualitas pelayanan terus dijaga kontinyuitasnya dan ditingkatkan dengan pola pola layanan yan baru yang lebih memberikan nilai tambah bagi pelanggan.

Kedua atribut tersebut perlu ditingkatkan agar pengguna merasa nyaman sehingga terbina hubungan baik untuk kelanggengan usaha perusahaan. Dampak lain dari promosi dan kualitas pelayanan yang bagus ini akan menarik perhatian pelanggan yang adalah orang asing yang juga banyak menggunakan alat transportasi laut menggunakan Batam Fast Ferry. Dengan semakin banyaknya orang asing yang masuk khususnya dari Singapura dan Malaysia, maka hal ini akan lebih menghdupkan perekonomian Batam dan dapat menopang dalam andil memajukan ekonomi nasional.

\section{DAFTAR PUSTAKA}


Dharmmesta, B.(2009.). Azas Azas dan Philosofi Marketing Modern, BPFE, Yogyakarta.

Ghozali, I. (2011). Aplikasi Analisis Multivariate Dengan Program SPSS. BP Universitas Diponegoro. Semarang

Kotler dan Kelller. (2012). Marketing Management 4th Edition, Englewood Cliffs, New Jersey, Prentice Hall.

Rangkuti, F. (2009). Strategi Riset dan Memenangkan Pasar Pemasaran Cetakan ke 12 PT. SUN Jakarta. 2017.

Sugiyono. (2013). Metode Penelitian Kuantiatif, Kualitatif dan R\&D. 225.Alfabeta. Bandung

Tjiptono, F. (2008). Service Management : Mewujudkan Layanan Prima (1st ed.). Andi Offset. Yogyakarta.

Wibowo, A. E. (2013). SPSS dalam Persepektif dan Riset Bisnis, Penerbit Gava Media Yogyakarta.

Wibowo, A. E. (2017). Analisis Faktor Faktor yang Mempengaruhi Behavioral Intention. Rekaman, 1(2017), 74-88. 